University of Nebraska - Lincoln

DigitalCommons@University of Nebraska - Lincoln

Sociology Department, Faculty Publications

Sociology, Department of

3-2004

\title{
Family Risk Factors and Prevalence of Dissociative Symptoms among Homeless and Runaway Youth
}

Kimberly A. Tyler

University of Nebraska-Lincoln, kim@ktresearch.net

Ana Mari Cauce

University of Washington

Les B. Whitbeck

University of Nebraska-Lincoln, Iwhitbeck2@unl.edu

Follow this and additional works at: https://digitalcommons.unl.edu/sociologyfacpub

Part of the Sociology Commons

Tyler, Kimberly A.; Cauce, Ana Mari; and Whitbeck, Les B., "Family Risk Factors and Prevalence of Dissociative Symptoms among Homeless and Runaway Youth" (2004). Sociology Department, Faculty Publications. 56.

https://digitalcommons.unl.edu/sociologyfacpub/56

This Article is brought to you for free and open access by the Sociology, Department of at DigitalCommons@University of Nebraska - Lincoln. It has been accepted for inclusion in Sociology Department, Faculty Publications by an authorized administrator of DigitalCommons@University of Nebraska - Lincoln. 
Published in Child Abuse \& Neglect, 28:3 (March 2004), pp. 355-366;

doi 10.1016/j.chiabu.2003.11.019 Copyright (C) 2004 Elsevier Ltd. Used by permission.

http:// www.sciencedirect.com/science/journal/01452134

The Seattle Homeless Adolescent Research and Education Project (SHARE)

is supported by the National Institute on Alcohol Abuse \& Alcoholism (AA10253-05).

Submitted January 27, 2003; revised October 13, 2003;

accepted November 9, 2003; published online February 25, 2004.

\title{
Family risk factors and prevalence of dissociative symptoms among homeless and runaway youth
}

\author{
Kimberly A. Tyler, ${ }^{*}$ Ana Mari Cauce, ${ }^{* *}$ and Les Whitbeck* \\ * Department of Sociology, University of Nebraska-Lincoln, \\ Lincoln, NE 68588-0324, USA \\ ** Department of Psychology, University of Washington, Seattle, WA, USA \\ Correspondence - Kimberly A. Tyler, ktyler2@unl.edu
}

\begin{abstract}
Objective: To examine family risk factors associated with dissociative symptoms among homeless and runaway youth.

Method: Three hundred and twenty-eight homeless and runaway youth were interviewed using a systematic sampling strategy in metropolitan Seattle. Homeless young people were interviewed on the streets and in shelters by outreach workers in youth service agencies.

Results: The current study revealed widespread prevalence of dissociative symptoms among these young people. Multivariate analyses revealed that sexual abuse, physical abuse, and family mental health problems were all positively associated with dissociative symptoms. No gender differences were found for any of the models.

Conclusions: Dissociative behavior is widespread among these youth and may pose a serious mental health concern. Some young people experience numerous stressors, and with few resources and little support available, many may invoke maladaptive strategies such as dissociative behavior to handle such situations, which may in turn be detrimental to their mental health. Unless youth are provided with programs and intervention, the cycle of abuse that they have experienced at home is likely to continue on the street.
\end{abstract}

Keywords: family abuse, homeless youth, dissociative symptoms

\section{Introduction}

High rates of physical abuse, sexual abuse, neglect, and parental rejection have been found among homeless and runaway youth (McCormack, Burgess, \& Gaccione, 1986; Powers, Eckenrode, \& Jak- 
litsch, 1990; Tyler, Hoyt, \& Whitbeck, 2000; Whitbeck, Hoyt, \& Ackley, 1997), and many young people cite these factors as reasons for leaving home (Janus, Archambault, Brown, \& Welsh, 1995). Although some studies on homeless and runaway adolescents (cf. Cauce et al., 1998; Whitbeck, Hoyt, \& Bao, 2000), have investigated the link between early maltreatment and mental health (e.g., depression, PTSD), none of this research has examined dissociative behavior as a mental health outcome despite its strong link with early maltreatment (cf. Carlson \& Putnam, 1993; Kisiel \& Lyons, 2001; Zlotnick et al., 1994). Given that a large number of homeless adolescents run from abusive family situations, they are an ideal sample for studying the broader issues of dissociative symptoms including prevalence and family correlates.

\section{Background}

Dissociation may be viewed as an adaptive coping mechanism that can protect people who have been exposed to severe trauma (Putnam, 1993). This process is thought to alter an individual's thoughts or actions by separating feelings from memories of specific traumatic incidents, such as sexual abuse (Irwin, 1994). Although dissociation typically peaks at ages 9-10 and then declines rapidly in adolescence, and leveling off by early adulthood (Putnam, 1993), exposure to early trauma may impede the normal age-related decline in dissociation leading to an increased likelihood of dissociating in adulthood.

Much of the research on dissociative behavior, which focuses on clinical samples, has found high levels of dissociation among children who have been sexually abused (Atlas \& Hiott, 1994; Kirby, Chu, \& Dill, 1993), while others have found an association between higher dissociative scores and histories of both sexual and physical abuse (Chu \& Dill, 1990; Zlotnick et al., 1994). Among adult men and women in the general population as well as amongst college students, early sexual abuse has been linked with higher scores on dissociation (Irwin, 1994; Sandberg \& Lynn, 1992). Recent findings also indicate that dissociation acts as a mediator between child abuse (i.e., sexual abuse, emotional abuse) and psychopathology such as eating disorders and various mental health outcomes (Kent, Waller, \& Dagnan, 1999; Kisiel \& Lyons, 2001). A meta-analysis on the Dissociative Experiences Scale (DES) found females were not more dissociative than their male counterparts (Van Ijzendoorn \& Schuengel, 1996). Few age differences were found in dissociative symptoms in a study of boys and girls preschool through late adolescence (Putnam, Hornstein, \& Peterson, 1996).

\section{Theoretical perspective}

The family environment in which children grow up is likely to influence their behavior. Some research finds that parents who suffer from mental health problems are likely to be neglectful, abusive, and/or inconsistent in their parenting (Kluft, 1987). Inconsistent parenting can cause the child to be stressed and confused, which may lead to dissociative tendencies (Mann \& Sanders, 1994). According to Kisiel and Lyons, "A natural, protective response to overwhelming traumatic experiences, dissociation can become an automatic response to stress" (2001, p. 1034). Given the numerous stressors that many young people experience, stress theory provides a useful framework for explaining the link between family background characteristics and dissociative behaviors. According to Wheaton, stressors are ... "conditions of threat, demands, or structural constraints that, by their very occurrence or existence, call into question the operating integrity of the organism" (Wheaton, 1999, p. 177). Although the majority of people adapt to stress and do not develop serious mental illness or behavioral problems, there are a number of individuals who become hopeless and engage in maladaptive behavior 
(e.g., dissociation). A central issue then is to explain why some individuals are negatively affected by stress while others are not (Aneshensel, 1999). If two people are exposed to similar stressors but each has different resources, the impact of the stressors is expected to be less for the person with more resources (Pearlin, 1999). While some people are successful in dealing with stress, others are poorly equipped because they have not acquired efficient coping strategies (Thoits, 1999). Stressors, such as physical abuse, neglect, and sexual abuse that many homeless and runaway youth have been exposed to in their family of origin (Janus et al., 1995; Tyler et al., 2000), may be too much to cope with and a breakdown may occur whereby some youth invoke dissociative behaviors, which can affect their functioning.

\section{Present study}

Although much of the research cited above finds a link between abuse and higher dissociative scores, many of the studies have not included multiple forms of maltreatment. Other problems include small sample sizes, exploratory and/or descriptive findings, and a focus only on small clinical samples. Further, we are unaware of any research to date that has investigated the link between family factors and dissociative symptoms among homeless and runaway youth.

The current study improves upon previous research by examining the prevalence of dissociative symptoms among a large sample of homeless youth who typically experience widespread trauma including high rates of abuse, neglect, parental rejection, and parents with mental health problems. Second, we use multivariate analyses to examine family factors and their association with dissociative behaviors. Specifically, we hypothesized that parental rejection, neglect, physical abuse, sexual abuse, and family mental health problems would be significantly associated with higher levels of dissociative symptoms. Based on a review of the literature, we did not expect age or gender differences.

\section{Method}

\section{Procedure}

Data are from the Seattle Homeless Adolescent Research and Education (SHARE) Project where young people were interviewed using a systematic sampling strategy that maximized locating homeless and runaway youth in metropolitan Seattle. This approach was used since it is well established that it is not possible to sample homeless populations randomly (Wright, Allen, \& Devine, 1995). Young people were interviewed over a period of 2 years (February 1996 to February 1998) by outreach workers who were trained youth workers with considerable experience interviewing and interacting with this group of young people and were very familiar with local street cultures. Interviewers approached all available youth who passed through or were at the locale and were between the ages of 13 and 21 . Street intercepts were made by approaching youth in the areas of the city frequented by homeless and runaway adolescents. These street intercept interviews were conducted at numerous locations such as coffee houses, restaurants, or outside if weather permitted.

Study eligibility required young people to be between the ages of 13 and 21 years and homeless. Our definition of "homeless" mandated that the youth currently resided in a shelter, on the street, or was living independently (e.g., friends, transitional living) because they had run away, had been pushed out, or had drifted out of their family of origin. If the youth had been on the streets less than one week, parental permission was obtained prior to the interview. In the state of Washington, ado- 
lescents can be considered emancipated at age 13. In addition to meeting this age criterion, however, youth were considered emancipated only if they were judged as having no significant contact with parents including no longer being financially dependent on them and did not spend any time at home for a week prior to the interview. If the youth met all these criteria, they were considered emancipated and were allowed to provide sole consent.

Respondents were informed that they could refuse participation, refuse single questions, or stop participating in the interview at any time. Due to the length of the questionnaire, the interview was conducted in two parts on separate days. Each section took approximately 11/2 to 2 hours to complete. The youth were paid $\$ 10$ for each section with a $\$ 5$ bonus for completing both sections. Thus, they were offered $\$ 25$ for the entire completed interview. The overall response rate was $95 \%$. The IRB at the University of Washington approved this study.

\section{Sample}

Although the original sample consisted of 374 youth, a total of 328 young people filled out the self-administered booklet, which included the Dissociative Experience Scale and those individuals are the focus of this study. Of the 328 youth, 174 (53\%) were male and 154 (47\%) were female. Ages ranged from 13 to 21 with a median of 17 years for the total sample. In terms of race, $47 \%$ were White, $7 \%$ African-American, 6\% Native American, 2\% Hispanic, and 2\% Asian. Thirty-six percent of the sample indicated that they were bi-racial or multi-racial.

\section{Measures}

Dissociative symptoms were assessed in the current study using the Dissociative Experiences Scale, which "is a self-report measure designed to assess the types and frequency of chronic dissociative symptoms" (Carlson \& Putnam, 2000, p. 621). The DES has been found to be a highly consistent scale with very good concurrent validity, particularly in the area of dissociative disorders and good predictive validity in the area of traumatic experiences such as post-traumatic stress disorder (PTSD) and abuse (Van Ijzendoorn \& Schuengel, 1996).

Respondents were asked to indicate how often they had a particular experience when they were not drinking or using drugs (see Appendix A for a list of the items). A DES score was computed for each respondent by summing the 28 items and then dividing by the same number of items (28). Cronbach's alpha for this scale in the current study is .92, which is consistent with a meta-analysis of 16 studies on the DES where the mean Cronbach's alpha was .93 (Van Ijzendoorn \& Schuengel, 1996).

Parental rejection was measured with five items from Elliott's Parental Rejection Scale (Brennan, 1974) in which the youth was asked to report the degree to which the parent/caretaker blamed, trusted, and cared about him or her; whether the parent/caretaker was unhappy with the things the youth did; and the degree to which the parent/caretaker thought everything was the youths' fault, even when he/she didn't deserve it. Response categories ranged from $1=$ strongly disagree to $5=$ strongly agree. Certain items were reverse coded and then the five items were summed such that the higher the score, the higher the rejection. The scale ranged from 5 (warmth, emotional closeness) to 25 (parental rejection). Cronbach's alpha for this scale in the current study is 80 .

Family neglect (adapted from Whitbeck \& Hoyt, 1999) was a single item in which adolescents were asked to indicate, "before you were on your own, how often has an adult or someone at least 5 years older than you abandoned you for at least 24 hours." A total of $43 \%$ of youth reported that they had been neglected. 
Family sexual abuse (adapted from Whitbeck \& Simons, 1990) consisted of seven items in which adolescents were asked, for example, before you were on your own (when you were under 18) how often has an adult "ever made you watch them do something sexual," "ever forced you to touch them sexually," and "ever messed around with you sexually." The seven items were dichotomized and summed but because the final indicator was still highly skewed, the categories were further collapsed into: 0 = never sexually abused; 1 = sexually abused a few times; and 2 = sexually abused at least once a month. A total of $26 \%$ of males and females reported experiencing sexual abuse on at least one occasion. Cronbach's alpha is .91 in the current study for the seven dichotomized items.

Family physical abuse was assessed using nine items based on the Conflict Tactics Scale (Straus \& Gelles, 1990). For example, youth were asked to report how often an adult had thrown something at him/her in anger, and threatened or assaulted him/her with a weapon. Each item was dichotomized, and then a count was done. The vast majority (82\%) experienced physical abuse at least once and many youth have experienced numerous types of physical abuse (e.g., been beaten up, had something thrown at them in anger). Cronbach's alpha for the nine dichotomized items in the current study is .78.

Family mental health was a single item indicator that asked the youth to indicate if someone in his/ her family (i.e., biological father, biological mother, biological brothers, biological sisters) had a mental health problem $(0=$ no; $1=$ yes $)$.

Gender and age were controlled for in the current study (males = 0; females $=1)$.

\section{Data analysis}

In order to examine the correlates of DES, six models were run using ordinary least squares regression. Because we wanted to see the individual effect of each family variable, we entered each of the variables individually. The standardized beta coefficients are presented $(\beta)$.

\section{Results}

Table 1 shows descriptive statistics for dissociative symptoms (based on the DES) for the total sample, females, and males. The mean score for the total sample is 36.5 (median $=33.2$ ) and these scores are very similar for males and females supporting Carlson and Putnam (2000) who report that the DES is

Table 1. Descriptive statistics for dissociative symptoms

\begin{tabular}{lllc}
\hline & Total & Female & Male \\
\hline$N$ & $328(100 \%)$ & $154(47 \%)$ & $174(53 \%)$ \\
Mean & 36.51 & 36.94 & 36.14 \\
Median & 33.21 & 34.29 & 32.68 \\
Standard deviation & 16.00 & 16.23 & 15.85 \\
Minimum & 10.36 & 11.43 & 10.36 \\
Maximum & 88.57 & 88.57 & 85.71 \\
\hline
\end{tabular}


Table 2. Correlation matrix

\begin{tabular}{lllllllll}
\hline & 1 & 2 & 3 & 4 & 5 & 6 & 7 & 8 \\
\hline 1 DES & - & & & & & & & \\
2 Gender $(0=$ male $)$ & .02 & - & & & & & & \\
3 Age & .01 & $-.23^{* *}$ & - & & & & & \\
4 Parental rejection & $.12^{*}$ & $.15^{* *}$ & -.02 & - & & & \\
5 Family neglect & $.19^{* *}$ & .06 & -.07 & $.19^{* *}$ & - & & & \\
6 Family sexual abuse & $.20^{* *}$ & $.13^{*}$ & .05 & .06 & $.16^{* *}$ & - & & \\
7 Family physical abuse & $.27^{* *}$ & .07 & -.04 & $.17^{* *}$ & $.52^{* *}$ & $.24^{* *}$ & - & \\
8 Family mental health & $.19^{* *}$ & -.01 & $.11^{*}$ & $.11^{*}$ & .09 & .06 & $.14^{*}$ & \\
& & & & & & & & \\
$M$ & 36.52 & .47 & 17.11 & 13.22 & .43 & .44 & 4.14 & .41 \\
$S D$ & 16.01 & .50 & 2.09 & 4.39 & .50 & .73 & 2.30 & .49 \\
\hline
\end{tabular}

$N=325$.

${ }^{a}$ Dissociative Experience Scale (DES).

$* p<.05$.

${ }^{* *} p<.01$.

not influenced by gender. Sixty percent of youth in the current study scored at or above 30 and $18 \%$ of the sample had a score of 50 or above on the DES (this result is not shown).

The bivariate correlations, means, and standard deviations for all study variables are presented in Table 2. The Dissociative Experiences Scale is significantly associated with all of the family variables including parental rejection $(r=.12)$; family neglect $(r=.19)$; family sexual abuse $(r=.20)$; family physical abuse $(r=.27)$; and family mental health problems $(r=.19)$. DES was not associated with gender or age.

Table 3 shows the multiple regression models for correlates of DES. Because we wanted to see the individual effect of each family variable with DES, we entered the variables in five separate blocks. Model 1 (only the control variables were included) revealed that there were no significant gender or age differences for DES and this is true of all subsequent models. In Model 2, parental rejection was

Table 3. Multiple regression models for correlates of DES

\begin{tabular}{lrrrrrr}
\hline Variables & Model 1: $\beta$ & Model 2: $\beta$ & Model 3: $\beta$ & Model 4: $\beta$ & Model 5: $\beta$ & Model 6: $\beta$ \\
\hline Gender $(0=$ male) & .02 & .00 & .00 & -.03 & -.03 & -.03 \\
Age & .02 & .02 & .03 & .01 & .01 & .00 \\
Parental rejection & & $.12^{*}$ & .09 & .08 & .07 & .06 \\
Family neglect & & & $.17^{* *}$ & $.14^{* *}$ & .05 & .04 \\
Family sexual abuse & & & & $.18^{* *}$ & $.15^{* *}$ & $.14^{* *}$ \\
Family physical abuse & & & & & $.21^{* *}$ & $.19^{* *}$ \\
Family mental health problems & & & & & $.15^{* *}$ & \\
Adjusted $R^{2}$ & .00 & .01 & .03 & .06 & .09 & .10 \\
\hline
\end{tabular}

$N=324$.

$* p<.01$.

$* * p<.05$. 
significant $(\beta=.12)$ indicating that youth who reported more rejecting parents had higher levels of dissociative symptoms. In Model 3, parental rejection is no longer significant but neglectful parents had children who scored higher on the DES $(\beta=.17)$. In Model 4 , neglect remains significant $(\beta=.14)$ even after adding in family sexual abuse $(\beta=.18)$, which is also significant. In Model 5, however, neglect drops out of the model when family physical abuse, which was positively associated with DES $(\beta=.21)$ was added. Sexual abuse still remains significant in this model $(\beta=.15)$. Family mental health problems in Model 6 was positively associated with DES $(\beta=.15)$ indicating that children who report family mental health problems have higher levels of dissociative behavior as do those who were sexually abused $(\beta=.14)$ and physically abused $(\beta=.19)$. Model 6 explained $10 \%$ of the variance in dissociative symptoms.

\section{Discussion}

The current sample was different from the general population in terms of the very high rates of abuse and neglect and DES scores found. However, the relationship between various family factors and dissociative symptoms were consistent with those found in other studies. Consistent with the literature in the general population (cf. Briere \& Runtz, 1988; Irwin, 1994; Mulder, Beautrais, Joyce, \& Fergusson, 1998) a history of sexual and physical abuse is associated with higher DES scores.

Although previous research on homeless and runaway youth has not focused on dissociative symptoms as a mental health outcome, our findings indicate that dissociative behavior is widespread among these youth and may pose a serious mental health concern. Sixty percent of youth in the current study scored at or above 30 and $18 \%$ of the sample had a score of 50 or above on the DES. According to Ross and colleagues "Scores above 20 are indicative of a substantial number of dissociative experiences in an individual's life" (Ross, Joshi, \& Currie, 1990, p. 1552) and scores above 30 are typically associated with meeting diagnostic criteria for multiple personality disorder or PTSD (Ross, Norton, \& Anderson, 1988). Consistent with much of the literature (cf. Putnam et al., 1996; Ross, Ryan, Anderson, Ross, \& Hardy, 1989; Van Ijzendoorn \& Schuengel, 1996), males and females did not significantly differ in their level of dissociative symptoms.

Youth in the current study reported high rates of sexual abuse, physical abuse, and neglect, which is consistent with previous findings (Janus et al., 1995; McCormack et al., 1986; Powers et al., 1990; Simons \& Whitbeck, 1991; Tyler et al., 2000). Congruent with the literature on the general population, having higher rates of abuse is associated with higher scores of dissociative symptoms (Briere \& Runtz, 1988; Irwin, 1994). The current findings are also consistent with Carrion and Steiner's (2000) study of 64 juvenile delinquents who found a positive association between physical abuse and neglect and dissociative behavior. Where the current findings differ from the general population are in terms of the rates. For example, Mulder et al. (1998) found that $6 \%$ of the general population suffers from high levels of dissociative behavior; in the current study, the rate for these youth was $60 \%$.

Multivariate analyses revealed that sexual abuse, physical abuse, and family mental health problems were significantly associated with dissociative symptoms and that these variables were more influential compared to neglect and rejection, which dropped out by the final model. The results indicate that other variables, in addition to abuse, are associated with dissociative symptoms.

Stressors such as sexual abuse, physical abuse, neglect, and rejection may affect everyday functioning of these youth. Consistent with stress theory, some youth may be low in resources and/or are poorly equipped because they lack support networks or have not acquired efficient coping strategies 
(Pearlin, 1999; Thoits, 1999). Therefore, dissociative behavior, for some, may be a form of coping that helps them block out pain or trauma associated with early abuse. Homeless youth also experience numerous strains on the street and with very limited resources and a lack of effective coping skills, stressors may overwhelm the capacities of some youth resulting in dissociative behavior.

Although the current study provides unique findings in terms of high scores of dissociative symptoms among homeless and runaway youth, there are limitations that need to be acknowledged. First, results of the present study are limited by respondents' self-reports. However, participants were informed that their responses would be confidential and the interviewers were very familiar with local street cultures. For these reasons, it is less likely that the respondents would be motivated to bias their responses. Moreover, comparisons done on runaway adolescents and their parents reveal that these young people do not appear to be over-reporting abuse within the home (Whitbeck et al., 1997). Another limitation is the retrospective nature of some of the measures, which may have resulted in some over-or-under-reporting. We also caution that the current findings are based on cross-sectional data; therefore, we cannot prove causation.

Despite these limitations, these results provide important assessment information for those working directly with these youth and for those designing and administrating intervention programs. First, they document high rates of dissociative symptoms among this population. Second, runaway and homeless males are as likely to score as highly on the DES as were females. Practitioners may overlook clinical signs in males if they are not looking for them. Third, family histories of neglect, sexual and physical abuse and family mental health problems are associated with dissociative symptoms. When adolescents are present with such backgrounds service providers need to be aware of the potential for dissociative processes. Although the field is uncertain of the long-term consequences of dissociative symptoms, researchers know that such symptoms are included in diagnostic criteria for borderline personality disorder (American Psychiatric Association, 2000). Such symptoms, therefore, may be precursors of serious mental illness or of current mental disorder that will require extensive evaluation and treatment. The high prevalence of dissociative symptoms implies that screeners should be available and part of the intake process when working with runaway and homeless youth.

In summary, the current study revealed that dissociative behavior is widespread among these homeless and runaway youth and may pose a serious mental health concern given that $60 \%$ of these youth scored at or above 30 and 18\% scored at or above 50 on the DES. Higher rates of sexual abuse and physical abuse prior to these young people leaving home is associated with higher levels of dissociative symptoms. Some youth experience numerous stressors and with few resources and little support available, many may invoke maladaptive strategies such as dissociative behavior to handle such situations, which may in turn be detrimental to their mental health.

\section{References}

American Psychological Association. (2000). Diagnostic and statistical manual of mental disorders (4th ed., Rev. ). Washington, DC: American Psychiatric Association.

Aneshensel, C. S. (1999). Outcomes of the stress process. In A. V. Horwitz \& T. L. Scheid (Eds. ), A handbook for the study of mental health: Social contexts, theories, and systems (pp. 211-227). New York, NY: Cambridge University Press.

Atlas, J. A. and Hiott, J., 1994. Dissociative experience in a group of adolescents with history of abuse. Perceptual and Motor Skills 78, pp. 121-122.

Brennan, T. (1974). Evaluation and validation regarding the national strategy for youth development. Boulder, CO: Behavior Research Evaluation Program. 
Briere, J. and Runtz, M., 1988. Symptomatology associated with childhood sexual victimization in a nonclinical adult sample. Child Abuse \& Neglect 12, pp. 51-59.

Carlson, E. B. and Putnam, F. W., 1993. An update on the dissociative experiences scale. Dissociation 6, pp. 16-27.

Carlson, E. B., \& Putnam, F. W. (2000). Dissociative Experiences Scale (DES). In A. John Rush Jr. (Ed. ), Handbook of psychiatric measures (pp. 621-623). Washington, DC: American Psychiatric Association.

Carrion, V. G. and Steiner, H., 2000. Trauma and dissociation in delinquent adolescents. Journal of American Academy of Child Adolescent Psychiatry 39, pp. 353-359.

Cauce, A. M., Paradise, M., Embry, L., Morgan, C. J., Lohr, Y., Theofelis, J., Heger, J., \& Wagner, V. (1998). Homeless youth in Seattle: Youth characteristics, mental health needs, and intensive case management. In K. Kutash, A. Duchnowski, \& M. Epstein (Eds. ), Community-based programming for children with serious emotional disturbances: Research and evaluation (pp. 611-632). Baltimore, MD: Brookes Publishing.

Chu, J. A. and Dill, D. L., 1990. Dissociative symptoms in relation to childhood physical and sexual abuse. American Journal of Psychiatry 147, pp. 887-892.

Irwin, H. J., 1994. Proneness to dissociation and traumatic childhood events. Journal of Nervous and Mental Disease 182, pp. 456-460.

Janus, M. D., Archambault, F. X., Brown, S. W. and Welsh, L. A., 1995. Physical abuse in Canadian runaway adolescents. Child Abuse \& Neglect 19, pp. 433-447.

Kent, A., Waller, G. and Dagnan, D., 1999. A greater role of emotional than physical or sexual abuse in predicting disordered eating attitudes: The role of mediating variables. International Journal of Eating Disorders 25, pp. 159-167.

Kirby, J. S., Chu, J. A. and Dill, D. L., 1993. Correlates of dissociative symptomatology in patients with physical and sexual abuse histories. Comprehensive Psychiatry 34, pp. 258-263.

Kisiel, C. L. and Lyons, J. S., 2001. Dissociation as a mediator of psychopathology among sexually abused children and adolescents. American Journal of Psychiatry 158, pp. 1034-1039.

Kluft, R. P., 1987. The parental fitness of mothers with multiple personality disorder: A preliminary study, Child Abuse. Child Abuse \& Neglect 11, pp. 273-280.

Mann, B. J. and Sanders, S., 1994. Child dissociation and the family context. Journal of Abnormal Child Psychology 22, pp. 373-388.

McCormack, A., Burgess, A. W. and Gaccione, P., 1986. Influence of family structure and financial stability on physical and sexual abuse among a runaway population. International Journal of Sociology of the Family 16, pp. 251-262.

Mulder, R. T., Beautrais, A. L., Joyce, P. R. and Fergusson, D. M., 1998. Relationship between dissociation, childhood sexual abuse, childhood physical abuse, and mental illness in a general population sample. American Journal of Psychiatry 155, pp. 806-811.

Pearlin, L. I. (1999). Stress and mental health: A conceptual overview. In A. V. Horwitz \& T. L. Scheid (Eds. ), A handbook for the study of mental health: Social contexts, theories, and systems (pp. 161-175). New York, NY: Cambridge University Press.

Powers, J. L., Eckenrode, J. and Jaklitsch, B., 1990. Maltreatment among runaway and homeless youth. Child Abuse E Neglect 14, pp. 87-98.

Putnam, F. W., 1993. Dissociative disorders in children: Behavioral profiles and problems. Child Abuse \& Neglect 17, pp. 39-45.

Putnam, F. W., Hornstein, N. and Peterson, G., 1996. Clinical phenomenology of child and adolescent dissociative disorders: Gender and age effects. Child and Adolescent Psychiatric Clinics of North America 5, pp. 351-360.

Ross, C. A., Joshi, S. and Currie, R., 1990. Dissociative experiences in the general population. American Journal of Psychiatry 147, pp. 1547-1552.

Ross, C. A., Norton, G. R. and Anderson, G., 1988. The dissociative experiences scale: A replication study. Dissociation 1, pp. 21-22.

Ross, C. A., Ryan, L., Anderson, G., Ross, D. and Hardy, L., 1989. Dissociative experiences in adolescents and college students. Dissociation 2, pp. 239-242.

Sandberg, D. A. and Lynn, S. J., 1992. Dissociative experiences, psychopathology and adjustment, and child and adolescent maltreatment in female college students. Journal of Abnormal Psychology 101, pp. 717-723. 
Simons, R. L. and Whitbeck, L. B., 1991. Sexual abuse as a precursor to prostitution and victimization among adolescent and adult homeless women. Journal of Family Issues 12, pp. 361-379.

Straus, M., \& Gelles, R. (1990). Physical violence in American families. New Brunswick, NJ: Transaction Publishers.

Thoits, P. A. (1999). Sociological approaches to mental illness. In A. V. Horwitz \& T. L. Scheid (Eds. ), A handbook for the study of mental health: Social contexts, theories, and systems (pp. 121-138). New York, NY: Cambridge University Press.

Tyler, K. A., Hoyt, D. R. and Whitbeck, L. B., 2000. The effects of early sexual abuse on later sexual victimization among female homeless and runaway youth. Journal of Interpersonal Violence 15, pp. 235-250.

Van Ijzendoorn, M. H. and Schuengel, C., 1996. The measurement of dissociation in normal and clinical populations: Meta-analytic validation of the dissociative experiences scale (DES). Clinical Psychology Review 16, pp. 365-382.

Wheaton, B. (1999). The nature of stressors. In A. V. Horwitz \& T. L. Scheid (Eds. ), A handbook for the study of mental health: Social contexts, theories, and systems (pp. 176-197). New York: Cambridge University Press.

Whitbeck, L. B., \& Hoyt, D. R. (1999). No where to grow: Homeless and runaway adolescents and their families. New York: Aldine de Gruyter.

Whitbeck, L. B., Hoyt, D. R. and Ackley, K. A., 1997. Families of homeless and runaway adolescents: A comparison of parent/caretaker and adolescent perspectives on parenting, family violence, and adolescent conduct. Child Abuse \& Neglect 21, pp. 517-528.

Whitbeck, L. B., Hoyt, D. R. and Bao, W., 2000. Depressive symptoms and co-occurring depressive symptoms, substance abuse, and conduct problems among runaway and homeless adolescents. Child Development 71, pp. 721-732.

Whitbeck, L. B. and Simons, R. L., 1990. Life on the streets: The victimization of runway and homeless adolescents. Youth \& Society 22, pp. 108-125.

Wright, J. D., Allen, T. L. and Devine, J. A., 1995. Tracking non-traditional populations in longitudinal studies. Evaluation and Program Planning 18, pp. 267-277.

Zlotnick, C., Begin, A., Shea, M. T., Pearlstein, T., Simpson, E. and Costello, E., 1994. The relationship between characteristics of sexual abuse and dissociative experiences. Comprehensive Psychiatry 35, pp. 465-470. 


\section{Appendix A}

I'm going to ask you questions about experiences that some people have. I want you to tell me how often you've had that experience when you are not drinking or using drugs. Have you ever ...

1. Forgotten what happened while you were driving or riding in a car or bus?

2. Been listening to someone talk then find you didn't hear part of what they said?

3. Find yourself some place but not know how you got there?

4. Found yourself dressed in clothes but not remember putting them on?

5 . Found something in your belongings and not know how it got there?

6. Has a stranger come up to you and called you by another name or insist they have met you before?

7. Watched yourself do something, like if you were looking at another person?

8. Been told that you don't recognize a friend or family member?

9. Have no memory of something important in your life, like a graduation (after age 6)?

10. Been accused of lying when you didn't think you had lied?

11. Looked in the mirror and not recognized yourself?

12. Felt that people or things or the world around you wasn't real?

13. Felt that your body doesn't belong to you?

14. Remember something in the past with so much detail that it felt real, like it was happening again?

15. Had something happen and not be sure if it's real or a dream?

16. Been some place familiar that you know, and feel it's strange or unfamiliar?

17. Gotten so wrapped up in a TV show that you stop noticing everything around you?

18. Gotten so wrapped up in a fantasy or daydream that it feels like it's really happening?

19. Some people can ignore pain, has that ever happened to you?

20. Ever stared into space, thinking of nothing and lost track of time passing?

21. Talked out loud to yourself?

22. Acted so differently in one situation compared to another that you felt like two different people?

23. Found that in some cases, like in sports or with friends or at work, you can do things easily that are usually hard for you?

24. Forgotten whether you did something or just thought about it, like not knowing whether you mailed a letter or just thought about it?

25. Found proof you did something even though you don't remember it?

26. Found notes or drawings that you know must be yours, but you can't remember writing them or drawing them?

27. Heard voices in your head that tell you to do things or make comments about things you are doing?

28. Felt like you're looking at things through a fog, so that people and things seem far away or unclear?

Items ranged from 1 (never) to 10 (all the time). 


\section{Résumé}

Objectif: Examiner les facteurs de risques familiaux associés aux symptômes de dissociation, dans une population de jeunes qui fuient leurs foyers ou qui sont sans abris.

Méthode: Des travailleurs oeuvrant dans des agences de services à la jeunesse ont interviewé un échantillon aléatoire de 328 jeunes fuyant leur foyer ou sans abris, dans la région métropolitaine de Seattle. Les entrevues ont eu lieu sur la rue ou dans des abris pour jeunes.

Résultats: L'étude révèle une prévalence importante de symptômes de dissociation parmi cette population de jeunes. Une analyse de variables multiples indique qu'il existe un lien entre ces symptômes et les agressions sexuelles, les mauvais traitements physiques et les problèmes de santé mentale dans leur famille. On n'a noté aucune différence entre les filles et les garçons.

Conclusions: Le comportement dissociatif est commun dans cette population de jeunes et pourrait leur poser des difficultés mentales sérieuses. Certains jeunes vivent des stress nombreux et ont peu de ressources et d'appuis; plusieurs ont recours à des solutions nocives telles que le comportement dissociatif, ce qui en retour peut occasionner des difficultés mentales. À moins que les jeunes aient à leur portée des programmes et des interventions aidantes, le cycle des sévices vécus dans leurs familles pourra se répéter dans les rues.

\section{Resumen}

Objetivo: Examinar los factores de riesgo familiar asociados con síntomas disociativos entre jóvenes "sin techo" y que se han fugado del domicilio.

Método: Un total de 328 jóvenes "sin techo" y que se han fugado del domicilio fueron entrevistados utilizando una estrategia de muestreo sistemático en el Area Metropolitana de Seattle. Los jóvenes fueron entrevistados en las calles y en los albergues por trabajadores de las agencias de atención a la juventud.

Resultados: El estudio reveló una amplia prevalencia de s'ýntomas disociativos entre esta población de jóvenes. Los análisis multivariados revelaron que el abuso sexual, maltrato f'ýsico y los problemas de salud mental en la familia estaban positivamente asociados con la existencia de s'ýntomas disociativos. No se observaron diferencias de género en ninguno de los modelos.

Conclusiones: La conducta disociativa es frecuente entre estos jóvenes y puede constituir un serio problema de salud mental. Algunos jóvenes están expuestos a numerosas situaciones estresantes y disponen de pocos recursos y apoyo accesible. Muchos de ellos pueden desarrollar estrategias desadaptativas, como la conducta disociativa, para afrontar la situación, lo cual puede afectar negativamente a su salud mental. A menos que se les proporcione a los jóvenes programas e intervenciones, el ciclo de maltrato que han experimentado en casa puede continuar en la calle. 